\title{
Relationship between the benefits of suplatast tosilate, a Th2 cytokine inhibitor, and gene polymorphisms in children with bronchial asthma
}

\author{
EIKO MATSUI, SHINJI SHINODA, OSAMU FUKUTOMI, HIDEO KANEKO, \\ TOSHIYUKI FUKAO and NAOMI KONDO \\ Department of Pediatrics, Gifu University Graduate School of Medicine, Gifu 501-1194, Japan
}

Received July 1, 2010; Accepted August 25, 2010

DOI: $10.3892 /$ etm.2010.149

\begin{abstract}
Although currently available antiasthmatic drugs are effective for many patients with bronchial asthma, some patients do not respond well to medications or exhibit more frequent adverse effects compared to other patients. Antiasthmatic treatment should be tailored individually according to the predispositions and pathophysiological conditions of patients. No reports have been made concerning the relationships between the effects of Th2 cytokine inhibitors and gene polymorphisms. The present study was therefore performed to investigate the relationships between gene polymorphisms known to be involved in allergy and cytokine production in peripheral blood mononuclear cells and the clinical efficacy of suplatast tosilate, a Th2 cytokine inhibitor, to clarify factors determining responses to treatment. A total of 20 children were enrolled in the study. The children were enrolled in a run-in period of 2 weeks and then received suplatast tosilate orally for 8 weeks. The children or their parents were instructed to keep an asthma diary to record changes in signs/symptoms of bronchial asthma before and after treatment. Concentrations of interferon (IFN)- $\gamma$ and interleukin (IL)-4 in the supernatant were determined using ELISA methods. Using the invader assay method, the genotypes of polymorphisms of the genes were determined. Treatment with suplatast tosilate was more effective in children without the $-444 \mathrm{~A} / \mathrm{C}$ polymorphism of the LTC4 synthase gene and in children without the IL-13 variant R110Q. In children who responded well, production of IFN- $\gamma$ was significantly increased after treatment. In this study, responses to suplatast tosilate were associated with SNPs of
\end{abstract}

Correspondence to: Dr Eiko Matsui, Department of Pediatrics, Gifu University Graduate School of Medicine, 1-1 Yanagido, Gifu 501-1194, Japan

E-mail: eikom@gifu-u.ac.jp

Key words: Th2 cytokine inhibitors, gene polymorphism, allergy, cytokine production, interferon- $\gamma$, interleukin-4, LTC4 synthase gene, interleukin-13 the LTC4 synthase and IL-13 gene as well as change in the production of IFN- $\gamma$ before and after drug administration.

\section{Introduction}

Allergic diseases such as bronchial asthma and atopic dermatitis develop as a result of the interaction of genetic and environmental factors (1). Several causative candidate genes for allergic diseases have been reported (2-6). Recently, treatment guidelines for bronchial asthma have been published and are utilized in clinical practice. Although antiasthmatic drugs are often effective in many patients with bronchial asthma, some patients may experience adverse effects on non-target organs and may exhibit lack of improvement due to the use of drugs inappropriate for their individual condition.

Although studies have shown that the effects of $\beta_{2}$-adrenergic agonists (7), leukotriene receptor antagonists $(8,9)$, and inhaled corticosteroids (10) are closely associated with gene polymorphisms, no reports have been made concerning the relationships between the effects of Th2 cytokine inhibitors and gene polymorphisms. In the present study, we investigated the relationships between the effects of suplatast tosilate, a Th2 cytokine inhibitor, and specific genetic polymorphisms and cytokines that are significantly associated with the presence/absence of effects of this drug.

\section{Subjects and methods}

A total of 20 children aged 3 to 17 years (14 boys and 6 girls) were enrolled in the study. After obtaining informed consent for participation in the study from the children or their parents, the children were enrolled in a run-in period of 2 weeks, after which blood samples were obtained. The children then took suplatast tosilate orally ( $6 \mathrm{mg} / \mathrm{kg} / \mathrm{day}$ ) for 8 weeks, and blood samples were taken at the end of the treatment period. Fig. 1 illustrates the study protocol. Before blood collection, the children or their parents received a full explanation of the design, methods, and expected results of the study and consented to blood sampling.

Evaluation of improvement of clinical signs/symptoms of bronchial asthma. The children or their parents were 


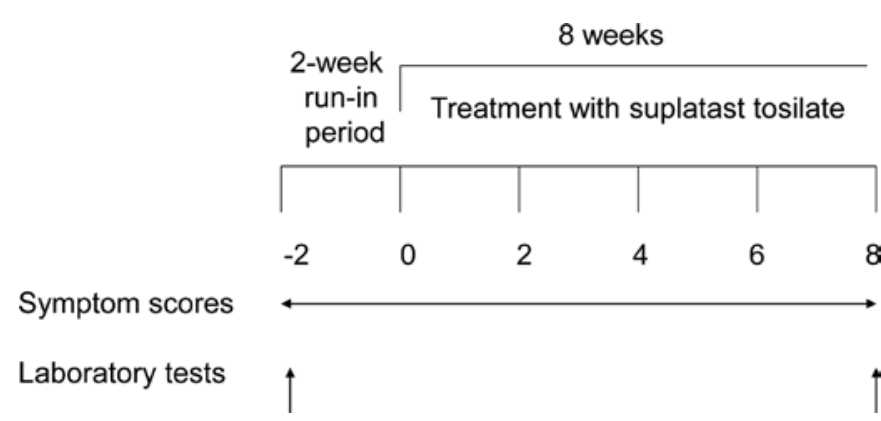

Figure 1. Study protocol. After an initial 2-week run-in period, suplatast tosilate was administered for 8 weeks.

instructed to keep an asthma diary to record changes in signs/ symptoms of bronchial asthma before and after treatment. Major, moderate, and minor asthmatic attacks were scored as 9,6 , and 3 points, respectively, and cough as 1 point. Total symptom scores during the 2 -week run-in period and the last two weeks of the 8-week treatment period were calculated and compared. Responders and non-responders were defined as children with and without a decrease in symptom score after treatment, respectively. No antiasthmatic drugs other than the study drug were administered during the run-in and observation periods.

Determination of eosinophil count and serum IgE level. Using aliquots of the blood samples obtained before and after treatment, the eosinophil count and serum $\operatorname{IgE}$ level were determined.

Determination of production of cytokines by peripheral blood mononuclear cells (PBMCs). PBMCs were isolated from heparinized blood samples using gradient centrifugation in Ficoll-Paque (Pharmacia, Uppsala, Sweden) and suspended at a density of $10^{6}$ cells $/ \mathrm{ml}$ in RPMI-1640 medium supplemented with $10 \%$ heat-inactivated fetal calf serum, $2 \mathrm{mmol} \mathrm{L}$-glutamine, $100 \mathrm{U} / \mathrm{ml}$ penicillin and $100 \mu \mathrm{g} / \mathrm{ml}$ streptomycin. PBMCs were cultured with $10 \mu \mathrm{g} / \mathrm{ml}$ phytohemagglutinin (PHA) (Gibco BRL, Grand Island, NY, USA) for $24 \mathrm{~h}$ at $37^{\circ} \mathrm{C}$ in the presence of $5 \% \mathrm{CO}_{2}$. After incubation, the concentrations of interferon (IFN) $-\gamma$ and interleukin (IL)- 4 in the supernatant were determined using enzyme-linked immunosorbent assay (ELISA) methods. IFN- $\gamma$ concentrations were measured with a human IFN- $\gamma$ ELISA kit (Ohtsuka, Tokyo, Japan); the limit of detection of which was $15.6-1000 \mathrm{pg} / \mathrm{ml}$. IL-4 concentrations were measured with a human IL-4 US ELISA kit (BioSource International, Camarillo, CA, USA); the limit of detection of which was $0.39-25.0 \mathrm{pg} / \mathrm{ml}$.

DNA isolation evaluation of gene polymorphisms. Genomic DNA was extracted from neutrophils with a SepaGene kit (Sankyo Junyaku Co., Ltd., Tokyo, Japan). Using the invader assay method, the genotypes of polymorphisms of genes known to affect the production of $\operatorname{IgE}$ and proinflammatory mediators were determined (Table I).

Statistical analysis. Relationships of symptom scores with eosinophil count, serum IgE level, cytokine concentrations,
Table I. Genotype and allele frequencies.

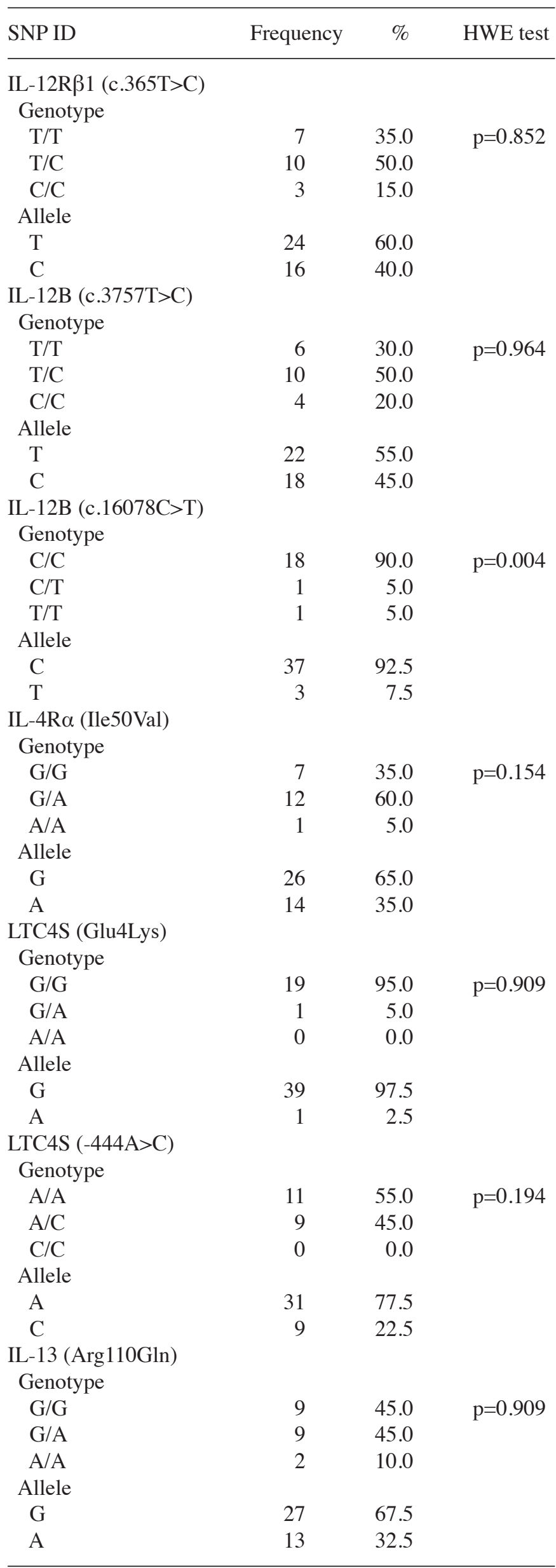


Table II. Asthma symptom scores before and after treatment with suplatast tosilate.

\begin{tabular}{lccc}
\hline & Responders $(\mathrm{n}=13)$ & Non-responders $(\mathrm{n}=7)$ & $\mathrm{p}$-value \\
\hline Asthma scores (pre) & $13.0 \pm 7.5$ & $7.2 \pm 12.9$ & 0.1980 \\
Asthma scores (post) & $1.8 \pm 2.4$ & $9.5 \pm 12.9$ & 0.0580 \\
Asthma scores ( $\Delta$ change) & $-11.8 \pm 6.7$ & $2.3 \pm 3.7$ & 0.0002 \\
\hline
\end{tabular}

P-values were obtained by the t-test.

A

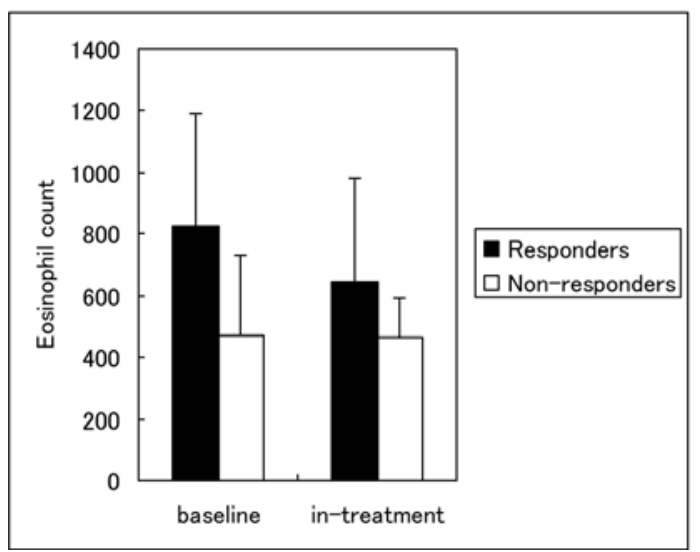

B

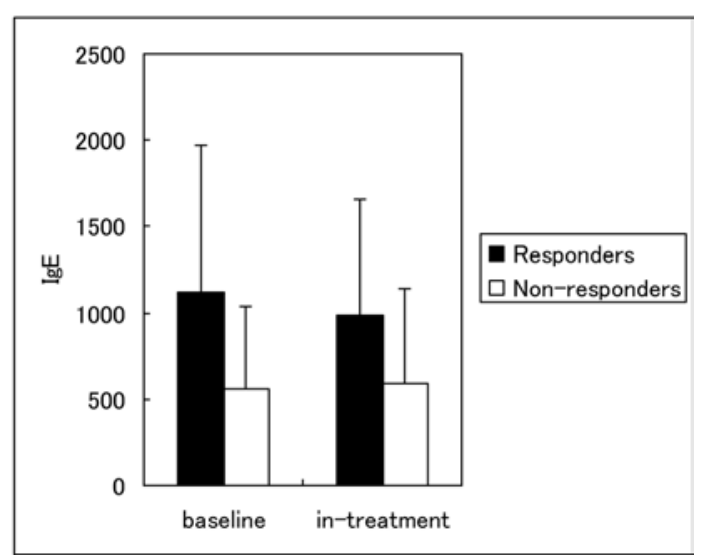

Figure 2. (A) Comparison of the eosinophil count. No significant differences between the responders and non-responders were observed for baseline or in-treatment values or the change in eosinophil count between the baseline and the treatment period. (B) Comparison of the serum IgE level. No significant differences between the responders and non-responders were observed for baseline or in-treatment values or the change in serum IgE level between the baseline and the treatment period.

Table III. Clinical characteristics of the patients.

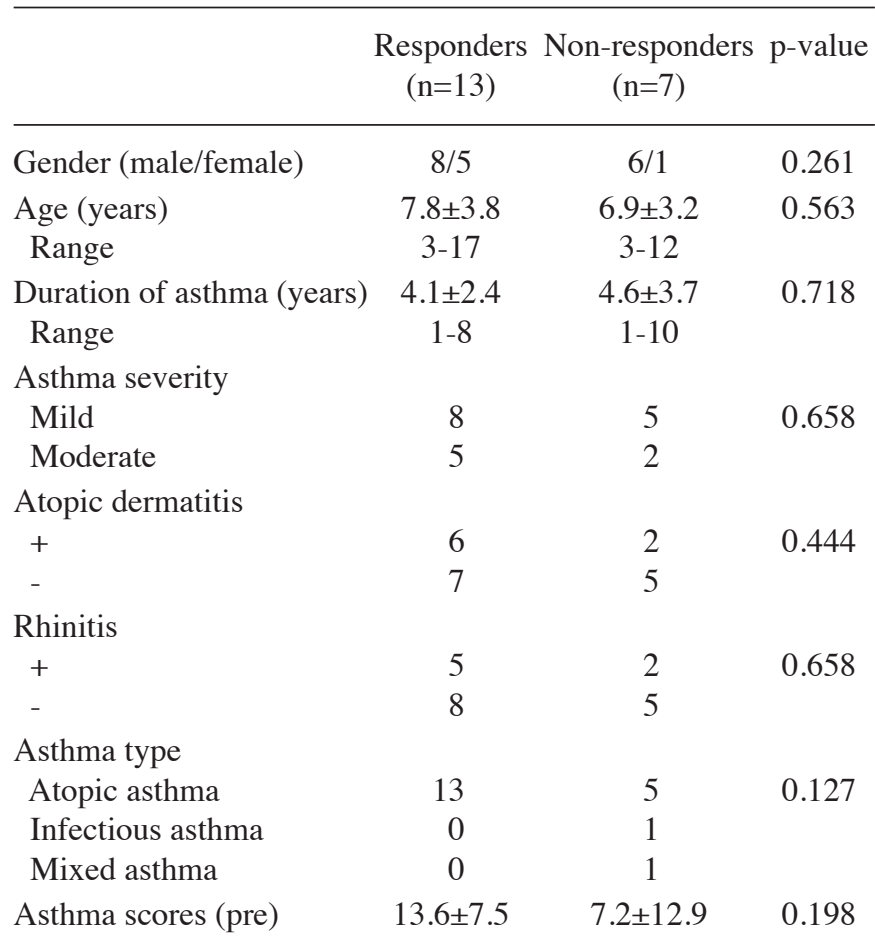

P-values for categorical data were obtained by the Chi-square test; $\mathrm{p}$-values for other data were obtained by the t-test. and genotypes of SNPs tested were examined using the Chisquare test or t-test.

\section{Results}

Evaluation of improvement in clinical symptoms of bronchial asthma. Responses to treatment with suplatast tosilate were assessed based on the descriptions in the asthma diary kept by the participants or their parents during the 2-week run-in period and the 8 -week treatment period (Table II). The symptom score during treatment was decreased from baseline in 13 patients $(8$ boys and 5 girls, mean age of $7.8 \pm 3.8$ years, referred to as the 'responders') and was unchanged or increased in 7 patients (6 boys and 1 girl, mean age of $6.9 \pm 3.2$ years, referred to as the 'non-responders'). No significant differences in age, severity of asthma, or prevalence of complications were observed between the responders and non-responders (Table III).

Relationships of the efficacy of treatment with the eosinophil count and serum IgE level. Comparisons of the eosinophil count and serum IgE level were carried out between the responders and non-responders to evaluate the relationships of these parameters with treatment efficacy. As shown in Fig. 2A and B, no significant differences were observed in baseline or in-treatment values or the change in these values between the baseline and the treatment period between the responders and non-responders. 
A

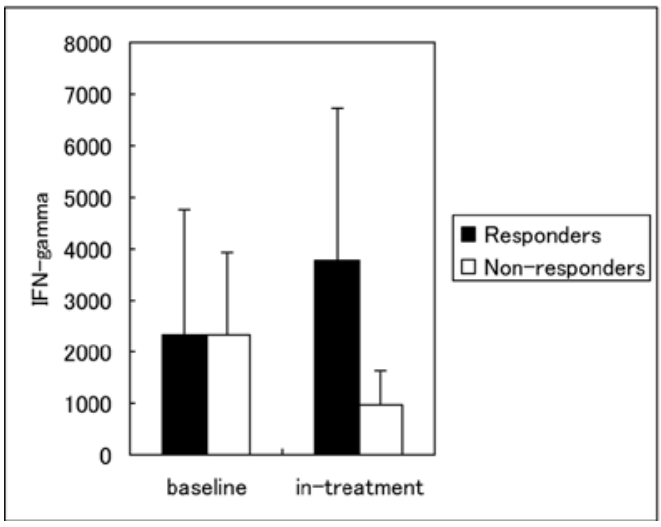

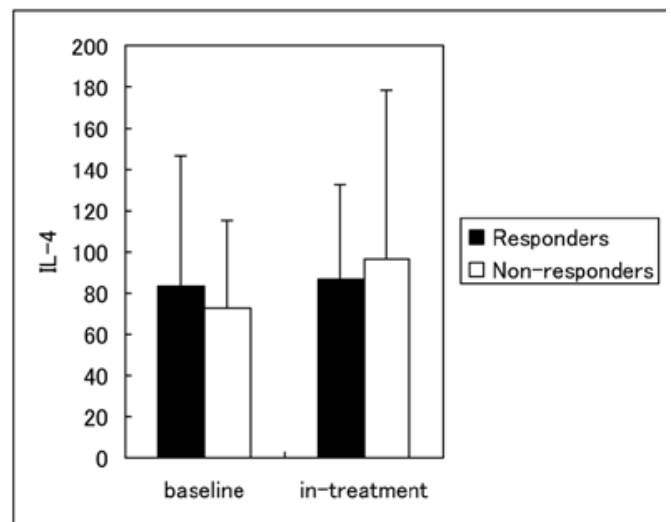

Figure 3. (A) Relationships of treatment efficacy with the amounts of INF- $\gamma$ produced in peripheral blood mononuclear cells before and after treatment were investigated. The change in IFN- $\gamma$ production between the baseline and treatment periods was significantly greater in the responders than in the nonresponders $(\mathrm{p}=0.011)$. (B) Relationships of treatment efficacy with the amounts of IL-4 produced in peripheral blood mononuclear cells before and after treatment were investigated. Production of IL-4 did not differ significantly between the responders and non-responders.

Table IV. Association between genotype and response to treatment with suplatast tosilate.

\begin{tabular}{|c|c|c|c|c|c|c|c|c|}
\hline & \multirow[b]{2}{*}{ Total no. } & \multicolumn{4}{|c|}{ Genotype } & \multicolumn{3}{|c|}{ Allele } \\
\hline & & $\mathrm{n}(\%)$ & $\mathrm{n}(\%)$ & $\mathrm{n}(\%)$ & $\mathrm{p}$-value & $\mathrm{n}(\%)$ & $\mathrm{n}(\%)$ & p-value \\
\hline IL12R $\beta 1(\mathrm{c} .365 \mathrm{~T}>\mathrm{C})$ & & $\mathrm{T} / \mathrm{T}$ & $\mathrm{T} / \mathrm{C}$ & $\mathrm{C} / \mathrm{C}$ & 0.384 & $\mathrm{~T}$ & $\mathrm{C}$ & 0.279 \\
\hline Responders & 13 & $4(30.8)$ & $6(46.2)$ & $3(23.0)$ & & $14(53.9)$ & $12(46.1)$ & \\
\hline Non-responders & 7 & $3(42.9)$ & $4(57.1)$ & $0 \quad(0.0)$ & & $10(71.4)$ & $4(28.6)$ & \\
\hline IL-12B (c.3757T>C) & & $\mathrm{T} / \mathrm{T}$ & $\mathrm{T} / \mathrm{C}$ & $\mathrm{C} / \mathrm{C}$ & 0.207 & $\mathrm{~T}$ & $\mathrm{C}$ & 0.386 \\
\hline Responders & 13 & $4(30.8)$ & $5(38.4)$ & $4(30.8)$ & & $13(50.0)$ & $13(50.0)$ & \\
\hline Non-responders & 7 & $2(28.6)$ & $5(71.4)$ & $0 \quad(0.0)$ & & $9(64.3)$ & $5(35.7)$ & \\
\hline IL-12B (c.16078C>T) & & $\mathrm{C} / \mathrm{C}$ & $\mathrm{C} / \mathrm{T}$ & $\mathrm{T} / \mathrm{T}$ & 0.299 & $\mathrm{C}$ & $\mathrm{T}$ & 0.950 \\
\hline Responders & 13 & $12(92.3)$ & $\begin{array}{ll}0 & (0.0)\end{array}$ & $1 \quad(7.7)$ & & $24(92.3)$ & $2(7.7)$ & \\
\hline Non-responders & 7 & $6(85.7)$ & $1(14.3)$ & $0 \quad(0.0)$ & & $13(92.9)$ & $1 \quad(7.1)$ & \\
\hline IL-4R $\alpha$ (Ile50Val) & & $\mathrm{G} / \mathrm{G}$ & $\mathrm{G} / \mathrm{A}$ & $\mathrm{A} / \mathrm{A}$ & 0.690 & G & A & 0.532 \\
\hline Responders & 13 & $4(30.8)$ & $8(61.5)$ & $1 \quad(7.7)$ & & $16(61.5)$ & $10(38.5)$ & \\
\hline Non-responders & 7 & $3(42.9)$ & $4(57.1)$ & $0 \quad(0.0)$ & & $10(71.4)$ & $4(28.6)$ & \\
\hline LTC4S (Glu4Lys) & & $\mathrm{G} / \mathrm{G}$ & $\mathrm{G} / \mathrm{A}$ & $\mathrm{A} / \mathrm{A}$ & 0.452 & G & A & 0.457 \\
\hline Responders & 13 & $12(92.3)$ & $1 \quad(7.7)$ & $0 \quad(0.0)$ & & $25(96.2)$ & $1 \quad(3.8)$ & \\
\hline Non-responders & 7 & $7(100)$ & $0 \quad(0.0)$ & $0 \quad(0.0)$ & & $14(100)$ & $0 \quad(0.0)$ & \\
\hline LTC4S $(-444 \mathrm{~A}>\mathrm{C})$ & & $\mathrm{A} / \mathrm{A}$ & $\mathrm{A} / \mathrm{C}$ & $\mathrm{C} / \mathrm{C}$ & 0.007 & A & $\mathrm{C}$ & 0.024 \\
\hline Responders & 13 & $10(76.9)$ & $3(23.1)$ & $0 \quad(0.0)$ & & $23(88.5)$ & $3(11.5)$ & \\
\hline Non-responders & 7 & $1(14.3)$ & $6(85.7)$ & $0 \quad(0.0)$ & & $8(57.1)$ & $6(42.9)$ & \\
\hline IL-13 (Arg110Gln) & & $\mathrm{G} / \mathrm{G}$ & $\mathrm{G} / \mathrm{A}$ & $\mathrm{A} / \mathrm{A}$ & 0.127 & $\mathrm{G}$ & A & 0.083 \\
\hline Responders & 13 & $8(61.5)$ & $4(30.8)$ & $1 \quad(7.7)$ & & $6(23.1)$ & $20(76.9)$ & \\
\hline Non-responders & 7 & $1(14.3)$ & $5(71.4)$ & $1(14.3)$ & & $7(50.0)$ & $7(50.0)$ & \\
\hline
\end{tabular}

Relationships between cytokine production and efficacy of treatment. Relationships of treatment efficacy with the amounts of INF- $\gamma$ and IL-4 produced by peripheral blood mononuclear cells before and after treatment were investigated (Fig. 3A and
B). The change in IFN- $\gamma$ production between the baseline and treatment periods was significantly larger in the responders than in the non-responders $(\mathrm{p}=0.011)$. Production of IL-4 did not differ significantly between the responders and non-responders. 
Table V. Association between genotype combination and response to treatment with suplatast tosilate.

\begin{tabular}{|c|c|c|c|c|c|c|c|}
\hline & \multirow[b]{2}{*}{ Total no. } & \multicolumn{3}{|c|}{ Genotype combination (1) } & \multicolumn{3}{|c|}{ Genotype combination (2) } \\
\hline & & $\mathrm{n}(\%)$ & $\mathrm{n}(\%)$ & $\mathrm{p}$-value & $\mathrm{n}(\%)$ & $\mathrm{n}(\%)$ & p-value \\
\hline IL12R $\beta 1$ (c.365T>C) & & $\mathrm{T} / \mathrm{T}$ & $\mathrm{T} / \mathrm{C}, \mathrm{C} / \mathrm{C}$ & 0.589 & $\mathrm{~T} / \mathrm{T}, \mathrm{T} / \mathrm{C}$ & $\mathrm{C} / \mathrm{C}$ & 0.168 \\
\hline Responders & 13 & $4(30.8)$ & $9(69.2)$ & & 10 (76.9) & $3(23.1)$ & \\
\hline Non-responders & 7 & $3(42.9)$ & $4(57.1)$ & & $7(100.0)$ & $0 \quad(0.0)$ & \\
\hline IL-12B (c.3757T>C) & & $\mathrm{T} / \mathrm{T}$ & $\mathrm{T} / \mathrm{C}, \mathrm{C} / \mathrm{C}$ & 0.919 & $\mathrm{~T} / \mathrm{T}, \mathrm{T} / \mathrm{C}$ & $\mathrm{C} / \mathrm{C}$ & 0.101 \\
\hline Responders & 13 & $4(30.8)$ & $9(69.2)$ & & $9(69.2)$ & $4(30.8)$ & \\
\hline Non-responders & 7 & $2(28.6)$ & $5(71.4)$ & & $7(100.0)$ & $0 \quad(0.0)$ & \\
\hline IL-12B (c.16078C>T) & & $\mathrm{C} / \mathrm{C}$ & $\mathrm{C} / \mathrm{T}, \mathrm{T} / \mathrm{T}$ & 0.639 & $\mathrm{C} / \mathrm{C}, \mathrm{C} / \mathrm{T}$ & $\mathrm{T} / \mathrm{T}$ & 0.452 \\
\hline Responders & 13 & $12(92.3)$ & $1 \quad(7.7)$ & & 12 (92.3) & $1 \quad(7.7)$ & \\
\hline Non-responders & 7 & $6(85.7)$ & $1(14.3)$ & & $7(100.0)$ & $0 \quad(0.0)$ & \\
\hline IL-4R $\alpha$ (Ile50Val) & & $\mathrm{G} / \mathrm{G}$ & $\mathrm{G} / \mathrm{A}, \mathrm{A} / \mathrm{A}$ & 0.589 & $\mathrm{G} / \mathrm{G}, \mathrm{G} / \mathrm{A}$ & $\mathrm{A} / \mathrm{A}$ & 0.452 \\
\hline Responders & 13 & $4(30.8)$ & $9(69.2)$ & & 12 (92.3) & $1 \quad(7.7)$ & \\
\hline Non-responders & 7 & $3(42.9)$ & $4(57.1)$ & & $7(100.0)$ & $0 \quad(0.0)$ & \\
\hline LTC4S (Glu4Lys) & & $\mathrm{G} / \mathrm{G}$ & $\mathrm{G} / \mathrm{A}, \mathrm{A} / \mathrm{A}$ & 0.452 & $\mathrm{G} / \mathrm{G}, \mathrm{G} / \mathrm{A}$ & $\mathrm{A} / \mathrm{A}$ & - \\
\hline Responders & 13 & $12(92.3)$ & $1(7.7)$ & & $13(100.0)$ & $0 \quad(0.0)$ & \\
\hline Non-responders & 7 & $7(100)$ & $0(0.0)$ & & $7(100.0)$ & $0 \quad(0.0)$ & \\
\hline LTC4S (-444A>C) & & $\mathrm{A} / \mathrm{A}$ & $\mathrm{A} / \mathrm{C}, \mathrm{C} / \mathrm{C}$ & 0.007 & $\mathrm{~A} / \mathrm{A}, \mathrm{A} / \mathrm{C}$ & $\mathrm{C} / \mathrm{C}$ & - \\
\hline Responders & 13 & $10(76.9)$ & $3(23.1)$ & & $13(100.0)$ & $0 \quad(0.0)$ & \\
\hline Non-responders & 7 & $1(14.3)$ & $6(85.7)$ & & $7(100.0)$ & $0 \quad(0.0)$ & \\
\hline IL-13 (Arg110Gln) & & $\mathrm{G} / \mathrm{G}$ & $\mathrm{G} / \mathrm{A}, \mathrm{A} / \mathrm{A}$ & 0.043 & $\mathrm{G} / \mathrm{G}, \mathrm{G} / \mathrm{A}$ & $\mathrm{A} / \mathrm{A}$ & 0.639 \\
\hline Responders & 13 & $8(61.5)$ & $5(38.5)$ & & 12 (92.3) & $1 \quad(7.7)$ & \\
\hline Non-responders & 7 & $1(14.3)$ & $6(85.7)$ & & $6 \quad(85.7)$ & $1(14.3)$ & \\
\hline
\end{tabular}

Relationships between SNPs and treatment efficacy. Using the invader assay method (11), the genotypes of SNPs of genes known to affect the production of IgE [interleukin (IL)-12, IL-12 receptor (IL-12R) $\beta 1$, IFN- $\gamma \mathrm{R} 1$, IL-4R $\alpha$ and IL-13 genes] and mediators (LTC4 synthase gene) were determined in the children enrolled in the study. Notably, the prevalence of the wild-type (A/A) genotype of the LTC4S -444 A/C polymorphism was significantly higher in the responders than in the non-responders ( $\mathrm{p}=0.024$ for allele prevalence, Table IV). Comparisons of the prevalence of genotype combinations revealed that the prevalence of the wild-type $(\mathrm{G} / \mathrm{G})$ genotype of the IL-13 R110Q polymorphism, compared with the G/A and A/A genotypes, was associated with favorable effects of treatment $(\mathrm{p}=0.043$, Table V).

\section{Discussion}

Studies of genetic factors in patients with bronchial asthma have been conducted since the late 1980s (2-6). In the present study on the relationships between genetic polymorphisms and the efficacy of a Th2 cytokine inhibitor in children with bronchial asthma, we investigated the SNP profiles of the IL-12, IL-12R $\beta 1$, IFN- $\gamma$ R1, IL-4R $\alpha$ and IL-13 genes, which affect IgE production, and LTC4 synthase, which affects the production of proinflammatory mediators, in order to evaluate the relationships between SNP profiles and response to treatment. In the present study, the LTC4S $-444 \mathrm{~A} / \mathrm{C}$ polymorphism was associated with favorable effects of suplatast tosilate. In 2000, Sampson et al reported that asthmatic patients with a variant allele in the LTC4S $-444 \mathrm{~A} / \mathrm{C}$ polymorphism exhibited increased improvement in respiratory function after treatment with leukotriene receptor antagonists (8). In the present study, treatment with the Th2 cytokine inhibitor, suplatast tosilate, $(12,13)$ was more effective in patients with the wild-type -444 $\mathrm{A} / \mathrm{C}$ polymorphism in the LTC4S gene than in patients with the variant LTC4S gene. It has also been reported that the expression of cysteinyl leukotriene 1 receptors is modified by IFN- $\gamma$ and IL-13 (14). Evaluation of the relationship between genotype combination and treatment efficacy revealed a relationship between the presence of the wild-type IL-13 gene and efficacy of the Th2 cytokine inhibitor. In addition, the change in IFN- $\gamma$ production between the baseline and treatment periods was significantly associated with efficacy of treatment. These findings suggest that the relationship between the LTC4S -444 A/C polymorphism and treatment efficacy may be explained by a change in the expression of cysteinyl leukotriene 1 receptors in responders. Further pharmacogenetic studies on gene polymorphism and expression should be performed in order to refine individually tailored treatment for asthmatic patients. 


\section{Acknowledgements}

This study was supported by Health and Labour Science Research Grants for Research on Allergic Disease and Immunology from the Ministry of Health, Labour and Welfare of Japan.

\section{References}

1. Kondo N, Matsui E, Kaneko H, Kato Z, Fukao T, Teramoto T, Shikano H, Aoki M, Onishi H, Tatebayashi K, Omoya K, Kondo M, Matsukuma E, Kasahara K and Morimoto N: Genetic defects in downregulation of $\operatorname{IgE}$ production and a new genetic classification of atopy. Allergol Int 53: 77-85, 2004.

2. Mitsuyasu H, Izuhara K, Mao XQ, Gao PS, Arinobu Y, Enomoto T, Kawai M, Sasaki S, Dake Y, Hamasaki N, Shirakawa T and Hopkin JM: Ile50Val variant of IL4R alpha upregulates $\operatorname{IgE}$ synthesis and associates with atopic asthma. Nat Genet 19: 119-120, 1998.

3. Heinzmann A, Mao XQ, Akaiwa M, Kreomer RT, Gao PS Ohshima K, Umeshita R, Abe Y, Braun S, Yamashita T, Roberts MH, Sugimoto R, Arima K, Arinobu Y, Yu B, Kruse S, Enomoto T, Dake Y, Kawai M, Shimazu S, Sasaki S, Adra CN, Kitaichi M, Inoue H, Yamauchi K, Tomichi N, Kurimoto F, Hamasaki N, Hopkin JM, Izuhara K, Shirakawa $T$ and Deichmann KA: Genetic variants of IL-13 signalling and human asthma and atopy. Hum Mol Genet 9: 549-559, 2000.

4. Tatebayashi K, Matsui E, Kaneko H, Fukao T, Kasahara K and Kondo N: IL-12B promoter polymorphism associated with asthma and IL-12B transcriptional activity. Allergol Int 54: 451-459, 2005.

5. Yoshikawa K, Matsui E, Kaneko H, Fukao $T$, Inoue $R$, Teramoto T, Shinoda S, Fukutomi O, Aoki M, Kasahara K and Kondo N: A novel single-nucleotide substitution, Glu 4 Lys, in the leukotriene $\mathrm{C} 4$ synthase gene associated with allergic diseases. Int J Mol Med 16: 827-831, 2005.

6. Aoki M, Matsui E, Kaneko H, Inoue R, Fukao T, Watanabe M, Teramoto T, Kato Z, Suzuki K, Suzuki Y, Kasahara K and Kondo N: A novel single-nucleotide substitution, Leu 467 Pro, in the interferon- $\gamma$ receptor 1 gene associated with allergic diseases. Int J Mol Med 12: 185-191, 2003.
7. Tan S, Hall IP, Dewar J, Dow E and Lipworth B: Association between beta 2 -adrenoceptor polymorphism and susceptibility to bronchodilator desensitisation in moderately severe stable asthmatics. Lancet 350: 995-999, 1997.

8. Sampson AP, Siddiqui S, Buchanan D, Howarth PH, Holgate ST, Holloway JW and Sayers I: Variant LTC(4) synthase allele modifies cysteinyl leukotriene synthesis in eosinophils and predicts clinical response to zafirlukast. Thorax 55 (Suppl 2): 28-31, 2000.

9. Asano K, Shiomi T, Hasegawa N, Nakamura H, Kudo H, Matsuzaki T, Hakuno H, Fukunaga K, Suzuki Y, Kanazawa M and Yamaguchi K: Leukotriene C4 synthase gene A(-444)C polymorphism and clinical response to a CYS-LT(1) antagonist, pranlukast, in Japanese patients with moderate asthma. Pharmacogenetics 12: 565-570, 2002.

10. Tantisira KG, Hwang ES, Raby BA, Silverman ES, Lake SL, Richter BG, Peng SL, Drazen JM, Glimcher LH and Weiss ST: TBX21: a functional variant predicts improvement in asthma with the use of inhaled corticosteroids. Proc Natl Acad Sci USA 101: 18099-18104, 2004.

11. Hall JG, Eis PS, Law SM, Reynaldo LP, Prudent JR, Marshall DJ, Allawi HT, Mast AL, Dahlberg JE, Kwiatkowski RW, de Arruda M, Neri BP and Lyamichev VI: Sensitive detection of DNA polymorphisms by the serial invasive signal amplification reaction. Proc Natl Acad Sci USA 97: 8272-8277, 2000.

12. Shim JJ, Dabbagh K, Takeyama K, Burgel PR, Dao-Pick TP, Ueki IF and Nadel JA: Suplatast tosilate inhibits goblet-cell metaplasia of airway epithelium in sensitized mice. J Allergy Clin Immunol 105: 739-745, 2000.

13. Suwaki T, Agrawal DK and Townley RG: Modification of eosinophil function by suplatast tosilate (IPD), a novel antiallergic drug. Int Immunopharmacol 1: 2163-2171, 2001.

14. Espinosa K, Bossé Y, Stankova J and Rola-Pleszczynski M: CysLT1 receptor upregulation by TGF-beta and IL-13 is associated with bronchial smooth muscle cell proliferation in response to LTD4. J Allergy Clin Immunol 111: 1032-1040, 2003. 